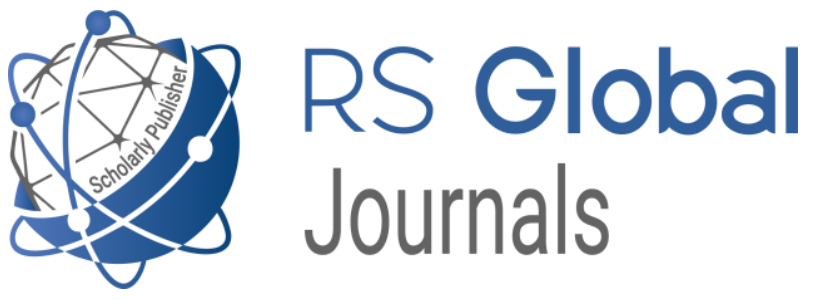

Scholarly Publisher

RS Global Sp. z O.O.

ISNI: 0000000484952390

Dolna 17, Warsaw, Poland 00-773

Tel: +48226022703

Email: editorial_office@rsglobal.pl

JOURNAL International Journal of Innovative Technologies in Social Science

p-ISSN

$2544-9338$

e-ISSN

2544-9435

PUBLISHER

RS Global Sp. z O.O., Poland

ARTICLE TITLE

EXPRESSION OF EMOTIONALITY AND EXPRESSIVENESS IN THE DIALOGUE

$\operatorname{AUTHOR}(\mathbf{S})$

Ismayilova Masma Aliyulla gizi

Ismayilova M. A. (2021) Expression of Emotionality and

ARTICLE INFO Expressiveness in the Dialogue. International Journal of Innovative Technologies in Social Science. 2(30). doi: 10.31435/rsglobal_ijitss/30062021/7594

DOI https://doi.org/10.31435/rsglobal_ijitss/30062021/7594

RECEIVED

30 April 2021

ACCEPTED

05 June 2021

PUBLISHED

09 June 2021

(c) (7)

LICENSE

This work is licensed under a Creative Commons Attribution 4.0 International License.

(C) The author(s) 2021. This publication is an open access article. 


\title{
EXPRESSION OF EMOTIONALITY AND EXPRESSIVENESS IN THE DIALOGUE
}

\author{
Ismayilova Masma Aliyulla gizi, Doctor Philosophy on Philology, Senior Lecturer, Foreign \\ Language Center, Philological Faculty, Azerbaijan State Pedagogical University, Azerbaijan
}

DOI: https://doi.org/10.31435/rsglobal_ijitss/30062021/7594

\section{ARTICLE INFO}

Received 30 April 2021

Accepted 05 June 2021

Published 09 June 2021

\section{KEYWORDS}

dialogue, colloquial speech, emotion, expressiveness, interjections, exclamatory sentences, intonation, English, Azerbaijani language.

\begin{abstract}
The article deals with the expression of emotionality and expressiveness in a dialogue.

The lexical system of the language contains words and ready-made constructions (for example, applause) that directly affect the emotional state. Different forms of such tools are used depending on the status of the interview. Praise, pleading, threats, blackmail, applause, etc. are the means chosen and included in speech at such moments.

The peculiarities of emotive and aesthetic functions, expressiveness in the dialogic speech in the modern Azerbaijani and English languages are systematized and analized on the basis of the concrete dialogues taken from the living speech and fiction. Stylistic-expressive grammatical forms in both languages are remarkable for their emotional peculiarities and don't depend on the type of speech. The special attention is given to interjections, exclamatory sentences, polysemantic words, reiteration, paralinguistic means, intonation, verbal context that play an important role in dialogues. It is also emphasized that in the dialogic speech participators are not content only with transmission of information but also try to influence the emotions of their conversation.
\end{abstract}

Citation: Ismayilova M. A. (2021) Expression of Emotionality and Expressiveness in the Dialogue. International Journal of Innovative Technologies in Social Science. 2(30). doi: 10.31435/rsglobal_ijitss/30062021/7594

Copyright: (C) 2021 Ismayilova M. A. This is an open-access article distributed under the terms of the Creative Commons Attribution License (CC BY). The use, distribution or reproduction in other forums is permitted, provided the original author(s) or licensor are credited and that the original publication in this journal is cited, in accordance with accepted academic practice. No use, distribution or reproduction is permitted which does not comply with these terms.

Introduction. In the dialogic speech participators are not content only with transmission of information. Each communicant tries to influence the emotions of the conversation. The more the desire to influence on interlocutor is, the more the attention to choice of language means and their use in the speech is. Expressiveness of information causes the more serious choice of language means $(20,105)$.

One of the participators of the dialogue, sometimes both of them influence each other's emotional state. When one of the announcers try to involve the other one in his/her range of interest in order to evoke a positive response this peculiarity is accompanied by intensification of emotionality, expressiveness in the dialogic speech. There are such words, constructions (for example greetings) in the lexical system of the language that have a direct impact on the emotional state. The different forms of such means are used depending on the status of conversation. Praise, request, threat, blackmail etc. are means that are chosen in such situations and included in speech.

Material. Expressiveness is one of the important peculiarities of colloquial speech, i.e. a dialogue. Expressiveness needs not only use of lexical means but also grammatical means. "Change of grammatical forms preserving vocabulary causes breach of the most fragile but significant stylistic connections and content" $(19,96)$.

The second person plural form also expresses respect in the language. When addressing to his/her interlocutor an announcer uses the suffixes of this form and creates a positive tone.

Incorrect expression of thoughts, breach of grammatical agreement influence the content and change listener's emotional state. 
Conversational style is one of the main functional styles of the modern English language (6,9). This affirmation is right not only for English but also for the Azerbaijani language. The lucid, harmonious, clear conversational language, conversational style are very important for any language.

The conversational style is reflected mainly in the oral dialogic speech. Both the Azerbaijani and English dialogic speech are very dynamic and changeable language style. Free speech, simplification of syntactic constructions, breach of language norms are typical of the conversational language. When deviation from existing forms of the language paradigm become traditional and manifests itself in the conversational language such deviation transferring to the other styles of the language changes its stylistic character. Thus the potential directions of the development of the language system manifest themselves in dialogues, too. Moreover all functions of the language including emotive and aesthetic ones are reflected to varying degrees in dialogues.

The peculiarities of emotive and aesthetic functions, expressiveness in the dialogic speech in the modern Azerbaijani and English languages can be studied on the basis of the dialogues taken from the living speech or fiction.

Stylistic-expressive, stylistic non-occasional, non-expressive, stylistic-expressive and stylisticneutral use of morphological forms in a dialogue can be noted. Stylistic-expressive grammatical forms are remarkable for their emotional peculiarities and don't depend on the type of speech.

In the dialogic speech the units that are far from one another from the morphological standpoint appear to be stylistic synonyms, for example, verbal and verbal-noun constructions: Birds were singing - Birds were in song;

A grammatical form used in the dialogic speech can get additional connotative meaning in the dialogic speech. The stylistic connotation of the grammatical form is a result of the discrepancy between denotative meaning and context in the dialogic speech. This discrepancy is formed during the use of the grammatical form. Expressiveness is a result of removal of discrepancy between the grammatical and lexical meanings of the form. Contradiction is revealed between the lexical and grammatical meanings instead of their synthesis $(11,79)$. Such expressiveness appears on the basis of the situational context.

In the modern English language the verbal form that indicates the third person singular has inherent expressiveness and is formed by means of the suffix -th-. This verbal form is considered to be archaic and is rare in the modern English language $(12,172)$.

The forms of the past tense of the verbs speak-spake, thrive-throve and the suffix -st- of the second person singular and archaic pronoun thou are used in order to intensify expressiveness, for example: Thou believest that there is one God; thou doest well: the devils also believe, and tremble. The General Epistle of James 2:19 (A. Rise "Pandora").

It is known that there are few morphological means used with adjectives and adverbs. In English adjectives have three degrees: positive, comparative and superlative. Regular adjectives make their comparative and superlative forms by adding -er and -est.

Suffixes and analytical forms are used to form these degrees in English. We usually add the ending -er to one syllable adjectives to make their comparative forms and -est to make their superlative forms. For adjectives with three or more syllables we usually add more/less and most/least. At present suffixes are superseded by the analytical form in the dialogic speech the conversational English.

Comparative and superlative degrees are formed by means of the more, and most. This form has both a stylistic nuance that is typical of the conversational language and an emotional form. Intensification of the quality of the adjective takes place during their use: He held up his finger. "You are the most clever woman I have ever known..." (A. Rice. ("Pandora").

Although it is very excruciatingly rich, horrifying sunny and more full of wonderfully exciting people than a pomegranate is of pips... (D. Adams "The Restaurant at the End of the Universe").

The most expressive state of the functional change of grammatical form takes place during transposition. At that time appreciation of emotion or stylistic expressiveness is a result of breach of the ordinary grammatical connections $(7,191)$. A substitutive member losing its functional quality during transposition becomes a carrier of two functions at the same time. At this time expressive enrichment becomes a form of unusual use $(18,7)$. Transition from an adjective to noun without changing of its form occurs very often in the speech, for example: my dear, my sweet, a regular etc. $(12,264)$. As a noun isn't used such phrases are more emotional and expressive, for example: Bridget, will you stop. Bloody. Staring at me when I am asleep (H. Fielding "Bridget jones: The Edge of 
reason"). Expressiveness is very high during the transition from syntactic constructions and sentences to adjectives, for example: I muttered, scarlet, as people stared and a sulky ruched - off -her - feet waitress bustled up (H. Fielding "Bridget Jones: The Edge of reason").

Pronoun $m e$ is often used instead of $I$ in the dialogic speech in the modern English language: "We helped", Ron said quickly. "Me and Hermione helped" (J.K. Rowling "Harry and the Goblet of Fire").

The phrases like "It's me" often occur in dialogues in English. They are idiomatic in nature and comply with standards of the English dialogic speech. Such constructions are stylistic nuances by nature. The phrases like "It's me" are often used in the everyday spoken language, for example: "He knew it was me", Harry told Ron and Hermione... (J.K. Rowling "Harry Potter and the Chamber of secrets").

No one would know it was us (J.K. Rowling "Harry Potter and the Chamber of secrets").

A pronoun in nominative case is used in the function of an object in the spoken language: "Between you and I", she interrupted, "I'd rather have them carryings...." (Sidney Sheldon "If Tomorrow Comes").

"Let's you and I not push poor Mike and further this week. We don't want him to snap". I muttered, preoccupied by the way he'd said "you and I" (St. Meyer "Twilight").

Such change takes place when the object expressed by the pronoun "I" moves away from the predicate or preposition because of another object and conjunction "and". Such forms occur only in the spoken language.

Replacement by the nominative case is typical of interrogative pronouns, too. Whom is typical of the written language in modern English: To whom did you give it? For whom are you looking?

They are correct forms from the grammatical standpoint. The preposition connected with the pronoun takes a distant position during replacement: "Who was that Howler from?" (J.K. Rowling "Harry Potter and the Order of the Phoenix") (34).

"Who were you having lunch with?" Jeff hesitated (Sidney Sheldon "If Tomorrow Comes").

If a preposition is used directly before an interrogative pronoun replacement doesn't take place. "Flashes of it", said Snape, his lip curling. "To whom did the dog belong?" (J.K. Rowling "Harry Potter and the Order of the Phoenix") (34).

"... You had your head in my fire. With whom have you been communicating?" (J.K. Rowling "Harry Potter and the Order of the Phoenix") (34).

A sentence is independent from the communicative standpoint and it is used as a unit that gives certain information in the speech. However there are some undifferentiated expressive means in the spoken language that have communicative independence, can indicate certain information in the speech and differ from ordinary sentences. Exclamatory sentences that are remarkable for their rich semantics and various structures in the spoken language take a special place among those expressive means. The communicative seme that forms the basis of exclamatory sentences plays a peculiar role in presentation of information and formation of questioning $(5,166)$. There are four groups of such communicative seems: 1) the ones that serve semantic, structural division; 2) used in daily life (greeting, congratulation, blessing, praise etc.); 3) emotives;4) interrogative-exclamatory expressions.

Exclamatory sentences can act on the level of a sentence and as a unit that is bigger than a sentence. Word order plays an important role in formation of their structural types.

The complete accurate clearance of its semantics is connected with the appropriate context or constitution.

Exclamatory sentences are autosemantic and synsemantic.

Language units and means carry out certain functions in the language system. The function is determined by a certain mode or form of an element in the system and its serve to this system. If the function of a sentence is connected with its communicative purpose the function of its elements, parts is formation of a communicative unit. Combinatorial opportunities of parts of a sentence are realized in the structure of a sentence (2).

The elements that form a sentence are not only verbs. Nouns and auxiliary parts of speech are also used in a sentence. All these elements can be grouped according to their mode of existence in the system, their role and significance in formation of communicative units and their constructive semantic function.

The elements in the communicative unit can be divided into three groups according to their constructive - semantic function:

1) the first function - independent use; 2) the second function- use as a component of a sentence; 3) the third function - use as a component of a word - combination. The different 
combinations of elements that carry out constructive - semantic functions form the character of a syntactic unit.

In linguistics autosemantic and synsemantic categories are notions accepted on the basis of the foresaid functions of the elements of communicative unit $(8 ; 9 ; 13 ; 16 ; 17)$. Autosemantics is connected with an independent communicative unit. Autosemantics is a peculiarity that is typical of syntactic structures that can be used independently and are the units of independent communication. Synsemantics is inherent in elements that don't carry out the function of an independent unit. Thus the first function carried out by elements of a sentence is autosemantic, the second and third functions carried out by them are synsemantic.

It is necessary to give attention to the following problem: the elements that form a sentence are words. These words are also units of the lexical system of a language, each of them has its own semantics. But some words don't have independent lexical meaning. Such words are grouped as auxiliary parts of speech in a language. As semantics of words makes it possible to differ them from one another such categories as autosemantics and synsemantics sometimes are used on the level of a word.

Autosemantic exclamatory sentences that express appraisal can also be in a nominative form, for example: Idler!; Meanie!; Good!

The dialogic speech is always remarkable for its concreteness, brevity, ellipticity. The information known to interlocutors are allowed in such a speech. So there is subtextual meaning in the semantics of the dialogic speech $(10,162)$.

The dialogic speech is remarkable for abundance of interjections. Though this fact is not a syntactic peculiarity of the dialogic speech it reflects its syntactic structure. The dialogic speech is more effective than the monologic speech. It is caused by wide use of interjections in it.

An interjection implies emotional attitude to the reality. Emotional - expressive peculiarities manifest themselves and are understood in the context of a dialogue.

Formation of the model of the sentence with the participation of interjections or combinations of them is a syntactic result of their use.

Discussion. A specific spoken model is realized by two-component communicative constructions. In such constructions unit of the notional part of speech carrying out a function of rheme motivates an interjection or exclamation act as a theme that appreciates rheme. It should be noted that the dialogic speech is rich in interlinear meanings, for example:

1.An interjection rheme:

"Oh, there you are. Looking for you. The R.T.O. says you go to Waterloo, and then proceed to Folkstone, he thinks" (R. Aldington).

"Oh! Rebecca, how can you" - was all that Briggs could say she turned her eyes.

- "Oh! Rebecca, how can you" - echoed my lord (W. Thackeray).

2. An interjection theme:

"Why, yes", said Dupin, drawlingly, between the whiffs of his meerschaum, "I really - think, G-, you have not exerted yourself - to the utmost in this matter.

You might - do a little more, I think, eh? (E. Poe).

In the dialogic speech an interjection often shows an interlocutor's readiness for a dialogue:

Roger spoke. "Chef-" "Uh-?" (W. Golding).

Thus an interjection is not only means that expresses emotional attitude to the reality in the dialogic speech. It is also means that carries out the phatic function of a language, creates communication between participants of a dialogue and continues the speech connection.

The dialogic speech is rich in interjections that increase the effectiveness of speech. For example, use of "uh" instead of usual, neutral "well" shows that a participant of a dialogue uses communicative of the low level of a spoken language and doesn't keep to the standard of speech as regards his/her interlocutor. In our opinion such means shouldn't be used in the process of teaching the dialogic speech.

A pronoun is another indicator of implicative meaning besides an interjection in the dialogic speech. It is actualized when a sentence is formed by a pronoun. In that case a speaker uses a model of a dialogue that isn't formed lexically. The implicit meaning is determined on the basis of the context, for example:

"You are not of the masons". "Yes, yes", I said; "yes, yes".

"Yes? Impossible! A mason?"

“A mason", I replied. 
"A sign" he said. "It is this", I answered, producing a trowel from beneath the folds of my roquelaire (E. Poe).

These heroes' speech is about Masonic symbol - a trowel. The remark "It is this" is understood only on the basis of the context.

Another example: "I am glad the little 'un isn't at home", Rawdon said, bitting his nails. "You remember him, Mac, don't you, in the riding school? Now he sat the kicker to be sure! Didn't he?"

"That he did, old boy", said the good-natured captain (W. Thackeray).

Thus a pronoun implicates information in certain volume. A pronoun ensures coherence of the dialogic speech. From the standpoint of the actual division of a sentence a pronoun is either a theme or a rheme depending on its position in a sentence.

The other parts of speech can also create implicative meaning. Unlike an interjection such parts of speech carry factual information. Presupposition is very important to understand the implicative meaning expressed in that form (99).

"Annl's been talking". - "A little. But if..." - "No, it's..." (J. Fowles).

"Just the name and address, right?" - "Right." - "Fifty pounds." - "Jesus" (O. Bleeck).

Though the implicative meaning can be expressed by the other parts of speech in the dialogic speech, this function is mainly carried out by means of interjections and pronouns.

There are enough emotive means in the language that ensure naturalness of communication. Analysis of the English dialogic speech shows that emotive means are used in a complex form to create an emotional background, for example:

A: Well, do you like fishing?

B: Yes, I sometimes go fishing in a river near my house in Scotland.

A: Well, here it is different. I go fishing on a lake. It's a hundred kilometers long! (amazement)

B: A hundred kilometers? (astonishment).

A: Yeah! There are fish this big! (boasting)

B: Really? (amazement, doubt).

A: Do you want to go?

B: OK! (consent, approval).

A: Right. You want a fishing line... (32).

The dialogic speech preserves its naturalness, vividness, emotionality by dint of emotive means $(14,4)$.

Expression of emotional state by means of a language is implementation of communicative functions by emotives.

The peculiarities of emotion, their group character, polysemy influence the polyfunctionality of emotive means.

This makes it difficult to use emotives in a language and understand them. The construction "What a book!" said by the different intonations in the different dialogic situations can express astonishment, amazement, disgust etc.

Use of emotive lexical means including interjections by native speakers is formed during the process of this language asquisition. So when expressing emotion any native speaker doesn't think about choice of concrete emotives and its use.

Application of polysemantic words including emotives is carried out by the following ways: 1) paralinguistic means (mimicry, gesture, bodily movement); 2) supersegmental means (intonation, tone, voice intensity); 3) non-verbal context (connection with a speech situation); 4) verbal context (use of additional words). Paralinguistic means accompanying a speech complete the emotionality of communication, give additional information about the interlocutor's state at that moment (calm, excited, confident, tired).

Paralinguistic means can be used in parallel with language units. The following forms and indicators of interjections occur in the English dialogic speech:

clicking sound; a sound like "t" is made by sucking rather than forcing air out (tut-tut)

a sound made with lips closed (h'm)

a cough (ahem)

a loud laugh (ho, ho)

a shout of laughter (Ha! Ha!) 
a quick short whistling breath either in or out (whew)

a cry (eureka, boo-hoo)

the sound that people make when hit in the stomach (oof)

a shout (boo! bravo!)

a noise, short hissing sound (psst) (24)

Supersegmental means play an important role in completion of imperative semantics and are widely used in the dialogic speech.

In the dialogic speech direct expression of the emotional state is realized by dint of non-verbal means, for example: to fling up ones hands, to whistle, to sigh etc. Speech can accompany these means. One of the peculiarities of use of emotives in a language is their contextuality. Their semantics is directly related to constitution:

A: How many Easter eggs did you get?

B: Six. What about you?

A: Five.

B: Great!

A: And I had eaten them all on Easter morning before lunch.

B: Did you?

A: And then I was sick!

B: Uh!

A: Yeah. Terrible! (Headway Elementary).

Isolation of such means as Did you? Great! Terrible! From the context doesn't allow to understand their meaning.

Interjections are used mainly in the spoken language. At the same time they are directly related both to situation and to the main decree.

Interjections express a person's mental state. It is difficult to understand it in writing:

- Ouch!

- Be careful.

- Yeah.

- Ouch!

- Oh! What a blow!

These interjections can be considered the main expressive means of emotion. Expression of emotion is their main functional load. Most of interjections are polyfunctional and it is their peculiarity.

The same interjection can express contradictory emotions in the different situations. Polysemantic words don't have such a peculiarity. For example ooh can express both pain and contentment, pleasure in English.

It should be noted that interjections which express the different meanings are pronounced with the different intonations.

There are a lot of universal interjections in a language. For example, oh, ah, o, well, wow etc. are universal for English.

The interjections that mainly express emotions are shorter and more concise. The interjections that have less semantics can be compound. meaning.

In English the interjection $a h$ has 30 meanings, but the interjection good heavens has only one

As interjections express the different emotions and are polysemantic their translation from one language into another one requires attentiveness.

A: Oh, dear! I'm going to sneeze.

B: Bless you!

A: Look!

B: There is my sister and her boyfriend.

Look! They are going to kiss.

Those who study English often consider the interjection Look! to be positive, but actually this interjection has negative meaning.

The emotional nature of exclamatory units isn't an indispensable condition. On the other hand, emotionality isn't always connected with an exclamatory sentence at all. 
The other types of communicative units that are not exclamatory sentences can be divided into three groups according to their structure:

1.The type of subject and predicate ( $\mathrm{s}+\mathrm{p})$ - Sən kişi ol! - Be a man! (19).

2. Word-combination that consists of secondary parts of a sentence:

- Old stuff!; - Puppy!; - Moron!; - Nonsense! (27).

The expressive units that don't form a syntagma:

- Fine!; - Excellent!

3. The exclamatory sentences of this group are accompanied by a number of shades of meaning. They cause perception of words with the different emotional nuances. The exclamatory sentences of the third group are remarkable for their structure and semantics. Sh. Bally includes the following factors in the notion of speech situation: a) things, creatures, actions and events perceted by sense organs during speaking; b) reason motive for conversation (situation known to interlocutors) $(9,96)$.

Exclamatory sentences are a person's subjective attitude to the events of the objective reality. There are some sentence constructions in the dialogic speech in which intonation becomes a decisive factor to express thoughts. Their communicative function is possible only through the intonation.

Intonation plays an important role in concretization of the semantics and content of sentences and determination of their communicative kinds in a certain communicative situation. Sometimes intonation causes regulation of sentences that seem to be "wrong" from the general grammatical standpoint in order to inform an addressee about the thought contained in them.

Let a stone fall on your head!

Let your trouble pass into my heart!

For God sake!

Semantic and structural function of reiteration in the sentences with exclamatory intonation can't be denied. Especially context has determinative significance in revelation and completion of meaning of context.

Sometimes it is impossible to determine this meaning by dint of intonation. Participation of context is important in repeated exclamatory sentences. Reiterations with exclamatory intonation make it possible to use the different structures $(1,24)$. When considering exclamatory reiterations from the phonetic standpoint it becomes clear that intensity of pronunciation is necessary for these reiterations.

Conclusions. Most of exclamatory reiterations belong to the group of emotional reiterations, and here two main shades of meaning attract attention:

1. discontent, opposite meaning, to dislike; astonishment; to express positive attitude in the different forms. Each of them has its specific structure and shades of meaning.

2. There are shades of irony, taunt, contempt in reiterations that mean emotional discontent.

- I want to eat!

- Eat, eat...I wish you to be taken ill with food $(30,258)$.

If the informative thought isn't expressed clearly before conversation an interlocuter hearing unexpected news and disagreeing with it uses reiterations that express astonishment. At that time the structure of exclamatory sentences is multilateral:

- I have come to escape death!

- Death! What death! $(3,65)$.

In such exclamatory sentences the particle "ey" is used together with a pronoun and intensifies sphere of influence of the repeated units:

- Get ahead and say it yourself.

- What shall I say, what is going on, ey! $(31,181)$. There are plenty of grammatical means that create emotionality in dialogues. These components are formed at the expense of particles, modal words.

Such communicative means of expressiveness play an important role in signification of the different relations. These means concentrate in one center, unit in order to get intensity of emotionality:

- I didn't know about it. After all it is...

- Well, what it is, it is!...

Well, what is it!

Interrogative-exclamatory seems are typical mainly of the spoken language. Such sentences are formed on the basis of questions-answers. Besides rhetorical questions, quasi questions are also typical of such a kind of sentences. In such sentences interrogative pronouns carry out grammatical and structural functions of exclamatory sentences and don't mean question; they often lose their pronoun function and become particles: 
- Has your father come to the city? - What are your saying?

Participation of grammatical means in formation of interrogative - exclamatory sentences is important. The paradigmatic composition of grammatical category in the negative form can be in the following oppositions:

1. entire and partial negation;

2. explicit (open) and implicit (hidden) negation.

The exclamatory sentences of the I group are formed in the different structural-semantic variants. The main deciding means in explicit and implicit exclamatory sentences is semantics. So this problem is studied in the psychological-linguistic aspects. Such study faces some theoretical challenges, ranging across fundamental theoretical questions about how emotional expression are represented.

\section{REFERENCES}

1. Agayeva F.M. Intonation of the Azerbaijani language. Baku: Maarif, 1978, 136 p.

2. Agayeva F.M. Some sentence constructions of the spoken language in Azerbaijani prose // Proceedings of APIL. Vol. XII, Baku: Publishing House of API, 1966, p.73-79

3. Agayeva F.M. Nominative constructions in the Azerbaijani language. Baku: Maarif, 1983, 98 p.

4. Agayeva F.M. Syntax of the oral speech. Baku: Maarif, 1975, 118 p.

5. Budagova Z.I. A simple sentence in the modern Azerbaijani language. Baku: Publication of Azerbaijani Academy of Sciences, 1963, $224 \mathrm{p}$.

6. Arnold I.V. Stylistics. The modern English language. Moscow: Nauka, 2009, 384 p.

7. Arnold I.V. The fundamentals of scientific researches in linguistics. Moscow: The highest school, 1991, $342 \mathrm{p}$.

8. Akhmanova O.S. Dictionary of linguistic terms. Moscow: The Soviet Encyclopaedia, 1966, 607 p.

9. Bally Ch. French stylistics. Moscow: Publishing House Insot, Literature, 1961, 396 p.

10. Brudniy A.A. Comprehension as a component of psychology of reading// The problem of sociology and psychology of reading. Moscow: Kniga, 1976, p. 162-172

11. Brusenskaya L.A., Kurochkina L.V. Intentional use of grammatical forms of nouns in the modern Russian language // Philological Sciences, №1, Moscow, 2001, p.73-81

12. Buzarov V.V. The fundamentals of theoretical grammar of the modern English language. Stavropol: Publication of SSU, 2007, $280 \mathrm{p}$.

13. Yermakova L.M. Scientific researches in linguistics. Moscow: Nauka, 2001, 118 p.

14. Zhelvis V.I. The emotive aspect of speech: Psycholinguistic interpretation of speech influence. Yaroslavl: Publication of YaPI, 1990, $81 \mathrm{p}$.

15. Kurnosova N.A. Functional-semantic field of communicatives of the Russian language //The problems of improving the teaching of a foreign language as means of interethnic communication. Part II, Kharkiv: Publication of Kh.U, 1991, p. 44-46

16. Lenert U. Problems of a question-answer dialogue // The new in foreign linguistics. Issue 23, Moscow: Progress, 1988, p.258-280

17. Sirotinina O.B. Texts, textoids, discourses in the zone of spoken speech // Rerson- Text- Culture: monograph. Yekaterinburg: Publication of Ural State University, 1994, p. 105-139

18. Ulanova S.B. Grammatical semantics as an object of grammatical stylistics (form- and word formation in the modern English language): Dissertation...candidate of philological sciences. Moscow: 2006, 204 p.

19. Chicherin A.V. Notes about the stylistic role of grammatical forms // A word and image. Moscow: Prosvechsheniye, 1964, p.93-101.

20. Sharonov I.A. Problems of description of communicative units consisting of syncategorematic words // Proceedings of Saratov University. Series Philology. Journalism. Issue 5, 2012, p.8-12

21. Buzarov Essentials of Conversational English Syntax. $2^{\text {nd }}$ ed., rev. and enl. Moscow: Kron-Press, 1998, 365 p.

22. Carter R. and M.Mc Carthy. Grammar and the spoken languages. Applied Linguistics 16 (2), 1995, p.141-158

23. Clark H.H., Carlson T.B. Hearers and speech acts// language. Vol. 58, 1982, №2, p. 332-371

24. Collins Cobuild. English Grammar. L. Harper Collins Publishers, 1995, 486 p.

25. Leech G. English grammar in conversation//Language Learning and Computers: Proceedings of the Chemnitz Symposium 20-21 February, 1998, p.1-10

26. Searle J.R. Background Meaning // Speech Act Theory and Pragmatics. Dordrecht etc.: Reidel, cop. 1980, p. $221-232$

27. Headway Elementary. Oxford, Oxford University press, 2008, $176 \mathrm{p}$.

28. Rowling J.K. "Harry Potter and the Chamber of secrets"). Shelbyville, Kentucky, Bloomsbury Publishing, $1999,181 \mathrm{p}$.

29. Rowling J.K. "Harry Potter and the Order of the Phoenix"). Shelbyville, Kentucky, Bloomsbury Publishing, $2003,960 \mathrm{p}$.

30. Sidney Sheldon "İf Tomorrow Comes". Donglas Harper Collins Publishers, 2009, 592 p. 